\title{
Manajemen Nyeri Terkini pada Pasien Pasca Seksio Sesarea
}

\author{
Muh. Ramli Ahmad, Rezki Hardiyanti \\ Departemen Anestesiologi, Terapi Intensif \& Manajemen Nyeri \\ Fakultas Kedokteran Universitas Hasanuddin/RSUP Dr. Wahidin Sudirohusodo Makassar
}

\begin{abstract}
Abstrak
Prosedur Seksio Sesarea (SS) seringkali menyebabkan nyeri sedang hingga berat selama 48 jam. Tujuan manajemen nyeri pascabedah adalah untuk memberikan kenyamanan pada pasien, menghambat impuls nosiseptif, dan menumpulkan respon neuroendokrin terhadap nyeri, yang dengan demikian mempercepat kembalinya fungsi fisiologis. Selain itu, manajemen nyeri yang adekuat pada pasien SS memungkinkan mobilisasi dini untuk mencegah risiko tromboemboli yang meningkat selama kehamilan dan pasien perlu bebas nyeri untuk merawat bayi serta memberikan ASI secara efektif. Mekanisme nyeri pascabedah terdiri dari sensitisasi perifer dan senstisasi sentral dari susunan saraf. Dampak klinik sensitisasi sistem saraf berupa hiperalgesia dan alodinia. Sensitisasi pascabedah akan mengakibatkan penderitaan bagi pasien sehingga pada akhirnya dapat meningkatkan angka morbiditas dan mortalitas pascabedah, oleh karena itu manajemen nyeri pascabedah harus ditujukan ke arah pencegahan dan meminimalkan terjadinya proses sensitisasi. Analgesia multimodal dengan mengkombinasi obat yang menghambat sensitisasi perifer dan sentral, dengan opioid sebagai analgesia penyelamat dapat menjadi pilihan untuk memberikan manajemen nyeri yang adekuat dan meminimalkan efek samping.
\end{abstract}

Kata kunci: analgesia multimodal, nyeri pascabedah, seksio sesarea, sensitisasi perifer, sensitisasi sentral

\section{Current Practice for Post Operative Pain Management in Caesarean Section}

\begin{abstract}
Caesarean section (CS) is frequently followed by moderate to severe pain up to 48 hours after surgery. Postoperative pain management is aimed to provide postoperative comfortness, inhibits nociceptive impulse, and blunts neuroendocrine response to pain, thus enhance the return of physiological function. Moreover, an adequate pain management in CS patients allows early mobilization in preventing the increased of thromboemboli risk during pregnancy, the need of patients to be pain free in taking care of the baby as well as effective breastfeeding. Postoperative pain mechanism consists of peripheral and central senzitisation of nervous system. Clinical impact of nervous system sensitization including hyperalgesia and allodynia. Postoperative sensitization resulted in patient's suffering that increase morbidity and mortality rate eventually. Therefore, postoperative pain management should be directed to prevent and minimalize sensitization process. Multimodal analgesia by combining analgesics inhibited peripheral and central sensitization, with opioid as rescue analgesic may be preferred to provide adequate pain management and to minimalize the adverse effects.
\end{abstract}

Key words: Caesarean section, central sensitization, multimodal analgesia, postoperative pain, peripheral sensitization. 


\section{Pendahuluan}

Nyeri berpotensi terjadi selama dan setelah prosedur pembedahan. Nyeri yang tidak diterapi dengan adekuat dapat menyebabkan sejumlah gangguan fisiologis dan psikologis pada wanita yang menjalani Seksio Sesarea (SS). Gangguan tersebut antara lain gangguan pemulihan, nyeri persisten, nyeri kronik, dan meningkatkan biaya perawatan. Manajemen nyeri pascabedah seringkali didapatkan jauh di bawah standar, dengan $30 \%-80 \%$ pasien mengalami nyeri sedang hingga berat pasca pembedahan. Nyeri yang dialami setelah SS dapat menyerupai nyeri yang dirasakan setelah histerektomi. ${ }^{1}$ Nyeri pascabedah diakibatkan oleh trauma jaringan langsung dan inflamasi yang menyertai. Sitokinsitokin inflamasi sistemik berkerja mensensitisasi saraf perifer dan meningkatkan persepsi nyeri. Inflamasi memainkan peran khusus yang signifikan pada nyeri yang terjadi setelah persalinan dikarenakan sitokin-sitokin inflamasi meningkat sebagai bagian dari proses persalinan. Setelah SS, konsentrasi sitokin luka operasi memiliki korelasi positif dengan konsumsi obat analgesia. Kisaran nyeri yang dilaporkan setelah SS lebih tinggi dibandingkan persalinan pervaginam. Akan tetapi, beban dan durasi nyeri yang dirasakan sama. ${ }^{1}$

Nyeri akut pascabedah merupakan salah satu faktor penting yang berhubungan dengan nyeri kronik pascabedah. Beberapa penelitian menunjukkan bahwa penggunaan blokade neuraksial perioperatif dapat mencegah sensitisasi sentral dan nyeri kronik. Penelitian mekanis dan klinis tambahan diperlukan untuk meningkatkan pemahaman mengenai nyeri persisten setelah SS. Terapi farmakologi dan non-farmakologi merupakan pendekatan yang optimal dan harus ditawarkan pada pasien ketika memungkinkan dan terdapat indikasi secara medis. ${ }^{1}$ Prosedur SS seringkali menyebabkan nyeri sedang hingga berat selama 48 jam. Tujuan manajemen nyeri pascabedah adalah untuk memberikan kenyamanan pada pasien, menghambat impuls nosiseptif, dan menumpulkan respon neuroendokrin terhadap nyeri, yang dengan demikian mempercepat kembalinya fungsi fisiologis. Selain itu, manajemen nyeri yang adekuat pada pasien SS memungkinkan mobilisasi dini untuk mencegah risiko tromboemboli yang meningkat selama kehamilan dan pasien perlu bebas nyeri untuk merawat bayi serta memberikan ASI secara efektif. Kolaborasi antarprofesi, pelatihan mengenai nyeri dan kontrol nyeri, dan analgesia yang dapat diberikan mandiri patient controlled analgesia (PCA) dapat berperan dalam peningkatan manajemen nyeri pasca SS. ${ }^{2-4}$

\section{Mekanisme Nyeri}

\section{Sensitisasi Perifer}

Paparan berulang terhadap stimulus noksius memicu potensial aksi diperbesar ke terminal sentral melalui neuron sensoris, sebaik dihantarkannya ke terminal perifer melalui cabang akson kolateral. Keadaan ini menyebabkan depolarisasi membran bersama dengan influks ion kalsium melalui voltageoperated calcium channel (VOCC), yang pada gilirannya menginduksi transmiter dilepaskan pada lokasi trauma dan mengaktivasi nosiseptor di sekitarnya. Pada kenyataannya, peningkatan dan pemanjangan respon terhadap stimulus dapat bermanifestasi sebagai hiperalgesia primer. Akumulasi kandungan intrasel yang dilepaskan, yang meliputi ATP, bradikinin, 5-HT, noradrenalin, prostaglandin E2, NGF, dan substansi P di lokasi sel yang rusak atau sel-sel inflamasi, yang juga dikenal sebagai sup inflamasi. Terdapat peningkatan konsentrasi proton $(\mathrm{H}+)$ di lokasi trauma, yang dengan demikian meningkatkan keasamannya. Keseluruhan mediator inflamasi ini mengikat dan diaktivasi oleh reseptor seasal masing-masing yang berlokasi pada neuron pasca sinaps dan kemudian mengaugmentasi sensasi nyeri melalui interaksi antara penghantar sekunder yang beragam. Contohnya, aktivitas sinyal adenosin monofosfat siklik (cAMP)/ protein kinase A (PKA) dan protein kinase $\mathrm{C}$ (PKC)/diasilgliserol (DAG) seluler terbukti penting untuk mempertahankan hiperalgesia perifer, sedangkan guanosin monofosfat siklik (cGMP) memainkan peran yang berlawanan dalam cAMP pada sensitivitas nosiseptor. ${ }^{5}$

Terdapat reseptor lain yang berada pada terminal 
aferen. Reseptor kapsaisin, kanal kation potensial reseptor transien, reseptor subfamili V (TRPV1) atau vaniloid untuk kapsaisin (VR1) yang berkerja sebagai transduser untuk stimulus termal yang berbahaya. Jalur mekanisme sinyal terlibat dalam sensitisasi terminal aferen yang meliputi peningkatan ion kalsium dan aktivasi reseptor berpasangan protein G (GPCR) yang menyebabkan peningkatan aktivitas adenil siklase (AC)/cAMP/PKA, fosfolipase C (PLC)/inositol trifosfat (IP3)/Ca2+ atau PLC/DAG/PKC. Di sisi lain, mediator-mediator inflamasi juga dapat merangsang pelepasan antidromik transmiter dari cabang kolateral nervus aferen, yang umumnya dikenal sebagai inflamasi neurogenik. Inflamasi neurogenik terjadi ketika mediatormediator inflamasi, seperti substansi P, CGRP, dan neurokinin dilepaskan secara lokal oleh neuron aferen. Akibat sensitisasi perifer adalah menghasilkan lebih banyak aktivitas nosiseptor aferen dan ketika informasi ini mencapai DH medulla spinalis, sensasi nyeri meningkat bahkan dengan kekuatan stimulus yang masih sama. ${ }^{5}$

\section{Sensitisasi Sentral}

Mekanisme transmitter dan pasca sinaps yang bertanggung jawab atas sensitisasi sentral masih belum diuraikan dengan jelas. Tahap pertama
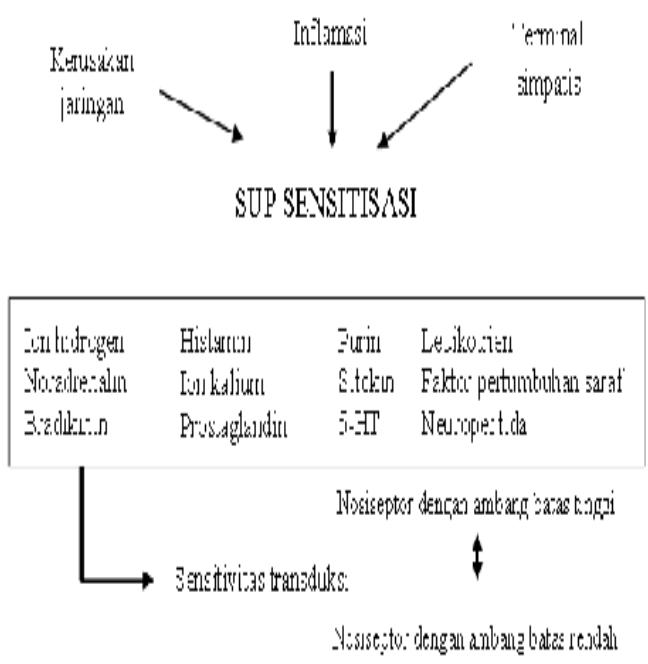

Gambar 1. Sensitisasi Perifer

(Dikutip dari: Rao M. Acute postoperative pain. Indian J Anaesth. 2006;50(5):340-4) bergantung pada potensial sinaps lambat yang dihasilkan oleh serat saraf $\mathrm{A} \delta$, dan $\mathrm{C}$ pada neuron kornu posterior. Tahap tersebut berlangsung hingga 20 detik, 2000 kali lebih lama dibandingkan potensial sinaps cepat yang dihasilkan oleh serat saraf $A \beta$. Potensial lambat ini dihasilkan dari pelepasan bersama oleh terminal akson nosisptor di medula spinalis, glutamat transmiter asam amino eksitatori dan neuropeptida, khususnya takinin substansi P dan neurokinin A. Durasi potensial lambat yang panjang tersebut menyebabkan akumulasi potensial selama input nosiseptor berulang frekuensi rendah, yang dengan demikian menghasilkan depolarisasi yang meningkat secara progresif dan berlangsung lama pada neuron kornu posterior. Beberapa detik input serat $\mathrm{C}$ menyebabkan beberapa menit depolarisasi pasca sinaps. Depolarisasi kumulatif ini disebabkan oleh aktivasi oleh glutamat reseptor asam N-metil-D-aspartat (NMDA) dan kemungkinan reseptor takinin oleh subtansi P dan neurokinin A. Aktivasi reseptorreseptor tersebut yang disebabkan oleh masukan kalsium melalui kanal ion pintu ligan dan pintu voltase serta aktivasi protein yang mengikat guanosine triphosphate (GTP), mengubah level kurir penghantar kedua pada neuron spinalis. Pada gilirannya, penghantar kedua mengganggu aktivitas protein kinase yang dapat mengubah
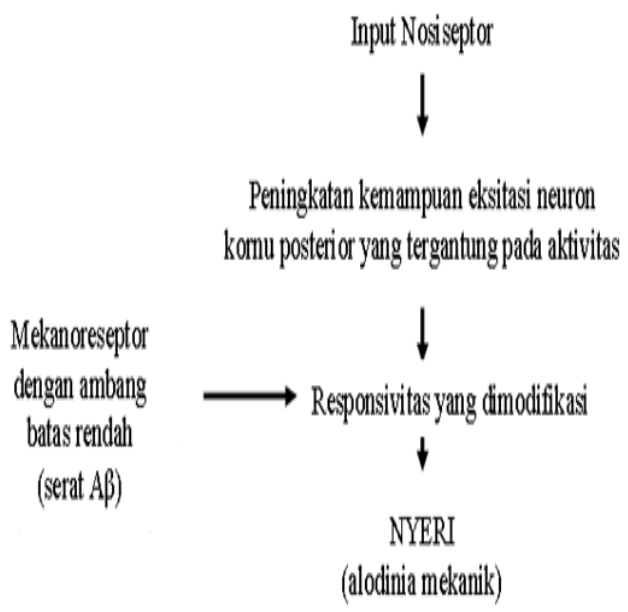

\section{Gambar 2. Sensitisasi Sentral}

(Dikutip dari: Rao M. Acute postoperative pain. Indian J Anaesth. 2006;50(5):340-4) 
fungsinya melalui fosforilasi protein seperti kanal ion atau enzim. Aktivasi protein kinase sehubungan dengan substansi $\mathrm{P}$ didapatkan menghasilkan efek umpan balik positif terhadap reseptor NMDA pada neuron spinalis, yang meningkatkan efikasinya dengan mengurangi kerentanannya terhadap blok magnesium. Penghantar kedua juga dapat mengganggu protein secara tidak langsung dengan mengubah level ekspresinya sebagai konsekuensi dari aktivasi produk gen yang merupakan faktorfaktor transkripsi yang dapat menghidupkan atau mematikan gen tertentu. ${ }^{7}$ Fungsi neuron sentral dapat dimodifikasi oleh proses yang tergantung pada aktivitas yang dipicu oleh input aferen nosiseptif. Karena aktivitas hanya merupakan inisiator perubahan seluler, tidak mengejutkan bahwa sekali sensitisasi sentral terjadi, obat anestesi lokal yang diberikan pada lokasi pemicu perifer tidak segera mengeliminasi sensitisasi sentral ini. Penelitian pada hewan menunjukkan bahwa terapi dengan obat anestesi lokal intratekal yang diberikan sebelum nyeri terjadi lebih efektif daripada obat anestesi lokal yang diberikan setelah nyeri dalam mengurangi perilaku terkait nyeri. Temuan yang sama pada subyek manusia yang diberikan obat anestesi lokal sebelum terjadi trauma memiliki durasi kerja yang lebih lama daripada terapi serupa yang diberikan pasca trauma. ${ }^{7}$

\section{Obat yang Menghambat Sensitisasi Perifer}

\section{Asetaminofen}

Asetaminofen banyak digunakan untuk analgesia pascabedah dan memberikan efek hemat opioid sekitar 10\%-20\%. Sebuah meta-analisis pada tahun 2012 mengidentifikasi empat RCT yang mengevaluasi asetaminofen dan efeknya terhadap konsumsi opioid setelah pembedahan mayor. Hanya sebuah penelitian yang memasukkan pasien obstetrik. Meta-analisis tersebut menunjukkan bahwa asetaminofen kurang efektif dibandingkan OAINS untuk mengurangi dosis opioid dan PONV. ${ }^{1}$

Perbandingan asetaminofen intravena dengan ibuprofen oral pada pasien pasca SS menunjukkan skor nyeri, konsumsi opioid, dan tingkat kepuasan pasien yang sama. Kombinasi OAINS dan asetaminofen terbukti bersifat sinergistik pada penelitian eksperimental manusia. Beberapa penelitian lain menilai efektivitas paracetamol intravena dan menyimpulkan bahwa asetaminofen intravena pada periode pascabedah setelah prosedur SS menghasilkan penurunan konsumsi narkotik untuk kontrol nyeri. ${ }^{1,8,9}$ Ketika dibandingkan dengan tramadol intravena, paracetamol mencapai kontrol nyeri yang sama memuaskan dengan tramadol setelah SS. Akan tetapi, tramadol menyebabkan efek samping yang signifikan pada ibu dibandingkan dengan paracetamol. Hal ini menunjukkan paracetamol intravena lebih baik daripada tramadol intravena sebagai analgesia pasca SS. $^{10}$ Paracetamol memiliki efek yang hampir sama dengan petidin dalam mengurangi nyeri pasca SS. Karena aturan yang rumit dan adanya restriksi penggunaan opioid serta tingginya angka efek samping opioid, pemberian paracetamol intravena dapat direkomendasikan sebagai alternatif yang baik dapat meringankan nyeri pasca pembedahan. Tidak adanya efek samping yang ditemukan pada penelitian yang membandingkan paracetamol dengan petidin tersebut membuat paracetamol aman digunakan. ${ }^{11}$ Karena banyaknya efek samping terkait opioid pada periode pasca pembedahan, penting untuk menemukan alternatif obat analgesia non-opioid. Penggunaan rutin asetaminofen yang terjadwal, selain OAINS, direkomendasikan dalam regimen analgesia pasca SS mengingat profil keamanan dan efikasinya yang telah terbukti. Belum ada bukti yang menunjukkan keunggulan asetaminofen intravena dibandingkan dengan obat oral yang ekuivalen dan dari segi biaya, sediaan intravena lebih mahal. ${ }^{12}$

Obat Anti-Inflamasi Non-Steroid (OAINS) OAINS menekan inflamasi dengan menghambat enzim siklooksigenase (COX) dan merupakan komponen kunci analgesia multimodal. OAINS efektif untuk nyeri perineum setelah persalinan pervaginam dan nyeri abdomen pasca SS. Ketika diberikan bersama dengan opioid, OAINS menghasilkan efek hemat opioid sebesar 30\%$50 \%$ yang dapat mengurangi efek samping terkait opioid. ${ }^{1}$ Sebuah meta-analisis menunjukkan 
bahwa penggunaan perioperatif OAINS yang dibandingkan dengan non-OAINS pada pasien SS menunjukkan skor nyeri yang lebih rendah, baik pada saat istirahat maupun pada saat bergerak. Selain itu, OAINS mengurangi konsumsi opioid dan efek mengantuk atau sedasi yang dihasilkan lebih rendah. Pengujian efek peningkatan analgesia dengan penggunaan OAINS sebagai bagian dari analgesia multimodal terhadap luaran yang terpusat pada pasien, seperti kepuasan pasien dan kualitas pemberian ASI juga harus dipertimbangkan. ${ }^{13}$

American Congress of Obstetricians and Gynecologists (ACOG) Task Force on Hypertension in Pregnancy merilis panduan untuk perawatan klinis hipertensi pada kehamilan pada tahun 2013 yang menyarankan untuk tidak memberikan OAINS pada pasien dengan hipertensi yang menetap lebih dari 1 hari pasca persalinan. Terdapat dua sumber yang mendasari rekomendasi ini. Pertama, data dari literatur kedokteran umum yang menunjukkan peran OAINS dalam menginduksi hipertensi pada pasien dewasa yang tidak hipertensi. Kedua, data dari laporan kasus yang dipublikasikan mengenai hipertensi pasca persalinan yang dianggap diinduksi oleh OAINS. Terdapat kekurangan data dari literatur obtetri untuk mendukung maupun menolak rekomendasi ini. ${ }^{14}$

\section{Ibuprofen}

Ibuprofen merupakan salah satu OAINS yang sering digunakan. Karena ibuprofen menghambat isoenzim COX-1 dan COX-2 secara nonselektif, selain komponen anti-inflamasi, analgesia, dan antipiretiknya, ibuprofen juga menghambat adhesi trombosit dan menyebabkan vasokonstriksi arteri renalis serta mengiritasi saluran cerna. Oleh karena itu, penggunaan OAINS pada pasien yang berisiko perdarahan dan gagal ginjal memerlukan perhatian. Meskipun demikian, pada sebagian besar ibu hamil tanpa faktor risiko perdarahan dan gagal ginjal, penggunaan OAINS dianggap aman. Ibuprofen bermanfaat bagi ibu menyusui karena transfer ke ASI terbatas. Pada sebuah penelitian berskala kecil yang menggunakan ibuprofen 400 mg oral setiap 6 jam selama 24 jam, kurang dari $1 \mathrm{mg}$ ibuprofen diekskresi ke dalam ASI pada periode 36 jam. Beberapa institusi menjadikan 600-800 mg setiap 6-8 jam sebagai dosis standar. ${ }^{1}$ Sebuah penelitian prospektif tunggal yang membandingkan asetaminofen dengan ibuprofen untuk kontrol nyeri pasca persalinan pada pasien dengan pre-eklamsia berat menunjukkan penggunaan ibuprofen pada hipertensi pasca persalinan yang terkait kehamilan berhubungan dengan tekanan darah yang lebih tinggi, yang menunjukkan adanya perburukan patologi pasien dan kebutuhan obat antihipertensi yang lebih besar. Mekanisme yang dapat menjelaskan efek OAINS terhadap peningkatan tekanan darah antara lain prostaglandin yang menghambat vasodilatasi, inhibisi prostaglandin E2 yang mengurangi natriuresis, dan kerja pada asam arakidonat yang menghasilkan komponen vasokonstriksi. ${ }^{15}$ Sedangkan pada sebuah penelitian acak terkontrol, ditemukan bahwa tidak ada perbedaan durasi kisaran tekanan darah dengan derajat berat pada kelompok ibuprofen dibandingkan dengan kelompok asetaminofen. ${ }^{14}$ Pada penelitian terbaru, ibuprofen tidak meningkatkan tekanan darah pasca persalinan pada wanita dengan gangguan hipertensi akibat kehamilan dan hipertensi ringan dibandingkan dengan wanita yang tidak mendapatkan OAINS. ${ }^{16}$ Sebuah penelitian lainnya membandingkan ibuprofen intravena dengan ketorolak intravena sebagai analgesia pasca SS. Penelitian ini gagal menunjukkan keunggulan ibuprofen intravena dibandingkan ketorolak intravena untuk mengurangi nyeri pasca pembedahan. Perhatian pada peningkatan perdarahan perioperatif juga mempengaruhi keputusan untuk menggunakan obat analgesia non-opioid pasca pembedahan. Kedua obat tersebut menghambat agregasi trombosit dengan menghambat COX-1 secara reversibel. Dengan potensi inhibisi otot polos uterus yang lebih rendah melalui efek COX2, ibuprofen secara teoretis menyebabkan perdarahan yang lebih rendah dibandingkan ketorolak. ${ }^{17}$

\section{Diklofenak}

Pemberian diklofenak supositoria (100 mg, 2 kali sehari) mengurangi konsumsi morfin dibandingkan dengan plasebo pada pasien pasca SS. Dosis rektal tunggal diklofenak $100 \mathrm{mg}$ 
memperpanjang rerata waktu yang diperlukan hingga pemberian obat analgesia pertama lebih dari 5 jam pada pasien yang mendapatkan morfin intratekal. Pasien yang mendapatkan morfin intratekal sebesar $0,0025 \mathrm{mg}$ tidak memerlukan obat analgesia penyelamat ketika diberikan diklofenak $75 \mathrm{mg}$ intramuskuler setiap 8 jam. ${ }^{1}$ Sebuah penelitian yang mengacak pasien dengan anestesi spinal menggunakan bupivakain dan fentanyl ke dalam kelompok yang diberikan salah satu dari tiga modalitas obat analgesia (asetaminofen, diklofenak, atau kombinasi diklofenak dan asetaminofen) menunjukkan bahwa pasien yang mendapatkan kombinasi diklofenak dan asetaminofen memerlukan morfin yang lebih rendah dibandingkan dengan yang hanya mendapatkan asetaminofen saja. ${ }^{1}$ Pada sebuah penelitian yang membandingkan diklofenak dengan pregabalin untuk analgesia pasca SS, laju penurunan skor nyeri dengan diklofenak lebih tinggi dibandingkan dengan pregabalin. Secara umum, karena diklofenak lebih efektif dibandingkan dengan pregabalin dan pasien lebih puas dengan sedikitnya kebutuhan penambahan analgesik, penelitian tersebut merekomendasikan penggunaan diklofenak untuk kontrol nyeri pasca SS. ${ }^{18}$

\section{Ketorolak}

Sebuah penelitian menunjukkan bahwa ketorolak mengurangi skor nyeri pada periode 2, 3, 4, 6, 12, dan 24 jam setelah SS dan juga mengurangi konsumsi opioid. Ketorolak sebelumnya dikontraindikasikan pada wanita menyusui, tetapi rekomendasi terbaru adalah dapat digunakan dengan hati-hati.1 Penelitian lain membandingkan tiga dosis morfin intratekal (50 $\mathrm{mcg}, 100 \mathrm{mcg}$, dan $150 \mathrm{mcg}$ ) yang dikombinasi dengan ketorolak untuk menentukan rasio dosisrespon, efikasi analgesia, dan efek samping. Tidak terdapat perbedaan pada penggunaan morfin selama 24 jam atau pada luaran nyeri dan kejadian mual. Penelitian tersebut menunjukkan bahwa morfin intratekal dengan dosis $50 \mathrm{mcg}$ menghasilkan tingkat analgesia yang sebanding dengan dosis $100 \mathrm{mcg}$ dan $150 \mathrm{mcg}$ ketika digunakan bersama dengan ketorolak intravena. ${ }^{19}$

Sebuahpenelitian yangmembandingkan ketorolak intravena dengan meperidin menunjukkan bahwa ketorolak dan meperidin memiliki efek yang sama dalam mengurangi nyeri pada pasien dengan tingkat nyeri pascabedah yang tinggi. Ketorolak dapat digunakan untuk kontrol nyeri pasca SS jika tidak ada kontraindikasi. Ketorolak memiliki efikasi yang sama dengan meperidin tetapi dengan efek samping yang lebih rendah dalam hal sedasi dan efek samping opioid lain. ${ }^{20}$ Penelitian retrospektif terbaru meneliti mengenai perbandingan pemberian ketorolak $15 \mathrm{mg}$ dengan ketorolak $30 \mathrm{mg}$ intraoperasi. Penelitian tersebut menunjukkan tidak ada perbedaan dalam hal penggunaan opioid pada kedua kelompok dosis ketorolak intraoperatif yang digunakan sebagai regimen analgesia multimodal pada wanita yang menjalani SS dengan anestesi neuraksial. ${ }^{21}$

\section{Penghambat COX-2 Selektif}

Penghambat COX-2 selektif memiliki manfaat potensial dibandingkan dengan OAINS nonselektif konvensional. Penghambat COX-2 selektif memiliki efek minimal pada adhesi trombosit dan oleh karena itu tidak mengganggu pembekuan darah yang menyebabkan perdarahan. Kategori OAINS ini memiliki efektivitas analgesia dan efek hemat opioid yang sama dengan OAINS konvensional pada pasien non-obstetri. Akan tetapi, pada pasien SS, penghambat COX-2 selektif tampaknya tidak seefektif OAINS konvensional. Selain itu, perhatian mengenai potensi peningkatan risiko gangguan kardiovaskuler dan trombosis, bersamaan dengan risiko peningkatan gangguan tersebut selama kehamilan dan pascabedah, mencegah penghambat COX-2 selektif memainkan peran besar dalam analgesia pasca persalinan. Kandungan parecoxib dan metabolit aktifnya, valdecoxib, dalam ASI sangat rendah serta skor neurologi dan adaptif neonatus normal setelah pemberian parcoxib $40 \mathrm{mg}$ intravena dosis tunggal setelah SS. ${ }^{1}$ Sebuah penelitian mengenai efikasi parecoxib $40 \mathrm{mg}$ intravena dosis tunggal untuk kontrol nyeri pasca pembedahan SS tidak menunjukkan efektivitas dalam mengurangi kebutuhan meperidin suplemental pasca SS. Akan tetapi, pemberian parecoxib $40 \mathrm{mg}$ intravena pada penelitian tersebut menunjukkan efektivitasnya dalam mengurangi skor nyeri yang mengantarkan 
pada kepuasan pasien. ${ }^{22}$

\section{Deksametason}

Glukokortikoid memiliki komponen analgesia dan antiemetik serta efek anti-inflamasi. Dosis tunggal deksametason prabedah dapat mengurangi nyeri pascabedah dibandingkan dengan plasebo pada pasien yang menjalani pembedahan dengan anestesi umum. Akan tetapi, penggunaan deksametason berhubungan dengan kadar gula darah yang lebih tinggi 24 jam pascabedah dan dengan demikian harus dihindari pad pasien dengan resistensi insulin. ${ }^{23}$ Sebuah ulasan sistematik dengan meta-analisis dan analisis penelitian sekuensial menyimpulkan bahwa deksametason intravena meningkatkan analgesia pascabedah setelah anestesi spinal dengan mengurangi konsumsi ekuivalen morfin 24 jam dan dengan memperpanjang waktu yang dibutuhkan hingga permintaan obat analgesia. ${ }^{22}$ Pada meta-analisis yang meliputi penelitian-penelitian pada pasien yang menjalani berbagai prosedur pembedahan, deksametason perioperatif dosis tunggal tidak mengganggu penyembuhan luka maupun meningkatkan risiko infeksi. Penambahan dosis tunggal deksametason prabedah meningkatkan analgesia pasca pembedahan dan mengurangi insidens PONV. Disarankan pemberian dosis antara 1,25-20 mg, tetapi dosis optimal tidak ditentukan. ${ }^{23}$

Pada penelitian mengenai deksametason $8 \mathrm{mg}$ intravena dosis tunggal yang ditambahkan pada regimen analgesia multimodal pascabedah yang meliputi morfin intratekal tidak mengurangi konsumsi opioid 24 jam pascabedah pada wanita yang menjalani SS dengan anestesi spinal. Penelitian lain membandingkan deksametason lokal dan intravena terhadap nyeri pascabedah dan pemulihan setelah SS dan menyimpulkan bahwa pemberian deksametason intravena dan infiltrasi subkutan lokal pada luka operasi mengurangi sensasi nyeri dan kebutuhan obat analgesia pascabedah hingga 24 jam tanpa komplikasi pascabedah. Akan tetapi, infiltrasi lokal ditemukan lebih efektif dibandingkan pemberian sistemik. Sedangkan pada penelitian lainnya, pemberian deksametason $0,1 \mathrm{mg} / \mathrm{kg}$ intravena sebelum pembedahan pada pasien yang menjalani SS dengan anestesi spinal cukup untuk mengurangi nyeri pascabedah, konsumsi tramadol total pada hari pertama pascabedah, dan memperpanjang waktu yang diperlukan hingga analgesia penyelamat. ${ }^{24-26}$

\section{Obat yang Menghambat Sensitisasi Sentral}

\section{Opioid}

Faktor-faktor yang mempengaruhi pilihan opioid antara lain kecepatan onset, durasi kerja, efektivitas, dan jenis serta frekuensi efek samping yang terjadi. Jika adanya efek samping mencegah analgesia yang adekuat, digunakan opioid atau ajuvan non-opioid yang lain. Pemilihan pasien berdasarkan pengalaman sebelumnya dan analgesia yang diinginkan juga harus dipertimbangkan. Meperidin sebelumnya telah banyak digunakan untuk analgesia pascabedah. Akan tetapi, American College of Obstetricians and Gynecologists (ACOG) dan American Pain Society menghentikan penggunaan meperidin pada pasien obstetrik dikarenakan akumulasi normeperidine pada neonatus dan mempengaruhi skor neurobehavioral. ${ }^{1}$ Sebuah penelitian membandingkan pemberian kombinasi sufentanil-tramadol dengan dosis berbeda untuk mengurangi nyeri dalam 24 jam pertama pasca SS. Penelitian ini menunjukkan bahwa VAS nyeri pascabedah menurun seiring dengan peningkatan moderat konsentrasi sufentanil dan tramadol dalam 24 jam pascabedah. Selain itu, konsumsi total sufentanil berkurang, tanpa peningkatan insidens efek samping. Dengan menyesuaikan konsentrasi kombinasi sufentanil-tramadol, analgesia pascabedah dapat ditingkatkan. ${ }^{27}$

PCA intravena memungkinkan pasien mengelola sendiri opioid dosis kecil sesuai kebutuhannya. American Society of Anesthesiologists (ASA) Task Force for Acute Pain Manage $\neg$ ment in the Perioperative Setting merekomendasikan untuk memilih modalitas seperti opioid epidural atau intratekal, opioid sistemik dengan PCA, dan teknik regional perifer dibandingkan dengan opioid intramuskuler yang diinstruksikan untuk diberikan "jika diperlukan". American Pain Society merekomendasikan penggunaan opioid PCA intravena ketika diperlukan pemberian 
analgesia intravena dan pemberian oral tidak tersedia. ${ }^{1}$ PCA telah digunakan untuk jalur intravena dan epidural untuk analgesia pasca SS. Sebuah penelitian yang membandingkan antara PCA intravena dan epidural dengan menggunakan fentanyl melaporkan skor nyeri yang lebih tinggi dan konsumsi fentanyl yang lebih besar pada pasien dengan jalur intravena, walaupun tingkat kepuasan pasien sama pada kedua kelompok. Beberapa penelitian yang membandingkan pemberian morfin PCA intravena dengan morfin epidural dosis tunggal untuk analgesia pasca SS menunjukkan bahwa analgesia dan tingkat kepuasan pasien lebih baik dan efek sedasi lebih rendah dengan morfin epidural, walaupun insidens pruritus lebih tinggi. ${ }^{1}$

Beberapa peneliti menganjurkan penggunaan obat analgesia oral dibandingkan PCA intravena dikarenakan terjadinya pemanjangan periode puasa pasca SS jarang ditemukan. Sebagian besar bukti menunjukkan bahwa pemberian opioid intravena tidak lebih baik dibandingkan dengan opioid oral untuk analgesia pascabedah. Faktanya, pasien yang dirandomisasi untuk mendapatkan oksikodon oral mengalami kejadian nyeri, mual, dan mengantuk 6 jam pasca SS yang lebih rendah dibandingkan dengan pasien yang diberikan morfin PCA intravena. Selain itu, pada penelitian yang membandingkan pemberian oksikodon oral dan oksikodon PCA intravena, didapatkan kontrol nyeri dan kepuasan pasien yang sebanding, tetapi kejadian mual lebih rendah pada pasien yang diberikan oksikodon oral. Oleh karena itu, pemberian opioid oral merupakan jalur pilihan jika dapat ditoleransi oleh pasien. Kelebihan pendekatan ini antara lain biaya lebih murah, memungkinkan mobilitas lebih awal, dan tingkat kepuasan pasien yang lebih besar. Opioid oral kerja lama tidak direkomendasikan pada periode awal pascabedah. ${ }^{1,28}$

Akan tetapi, berdasarkan sebuah penelitian, persentase pasien yang menggunakan opioid oral pasca SS menurun secara signifikan dari $68 \%$ hingga $45 \%$ setelah inisiasi peningkatan kualitas tanpa mengubah skor nyeri maupun keseluruhan kepuasan. Serupa dengan hal tersebut, persentase pasien yang dipulangkan dengan merespkan opioid menurun secara signifikan dari 91\% hingga $40 \%$. Temuan tersebut menunjukkan bahwa ketika obat analgesia non opioid termasuk asetaminofen dan OAINS digunakan dengan interval terjadwal, mayoritas pasien tidak memerlukan opioid oral untuk mencapai kontrol nyeri efektif pasca SS. Oleh karena itu, opioid sebaiknya tidak diberikan secara rutin setelah SS. Hal ini sesuai dengan American College of Obstetricians and Gynecologists merekomendasikan bahwa pemberian opioid sebaiknya hanya sebagai tambahan untuk pasien dengan nyeri yang tidak terkontrol meslkipun pemberian terapi non-opioid lini pertama telah adekuat. $^{29}$

\section{Antikonvulsan}

Gabapentin merupakan obat antikonvulsan yang memiliki komponen analgesia, khususnya nyeri neuropati. Gabapentin telah diteliti secara luas dalam pengelolaan nyeri kronik dan untuk analgesia pasca pembedahan, di mana obat ini dihubungkan dengan lebih banyak penghentian opioid. Akan tetapi, perannya pada pasien pasca SS yang belum mendapatkan opioid sebelumnya masih belum jelas. Sebagai bagian dari regimen obat analgesia, gabapentin oral $600 \mathrm{mg}$ yang diberikan sebelum pembedahan berhubungan dengan skor nyeri yang lebih rendah pada saat bergerak maupun istirahat. Akan tetapi, insidens sedasi lebih tinggi pada kelompok gabapentin dibandingkan pada kelompok plasebo. ${ }^{1}$

Pada sebuah penelitian tindak lanjut, dibandingkan pemberian gabapentin $300 \mathrm{mg}$ dan $600 \mathrm{mg}$ dengan plasebo dengan harapan untuk menemukan dosis yang efektif dengan sedasi yang lebih rendah. Sayangnya, penelitian tersebut gagal menunjukkan efikasi gabapentin pada kedua dosis. Gabapentin dapat memiliki peran dalam analgesia pasca SS pada pasien dengan nyeri kronik dan pasien dengan toleransi opioid. Sebuah penelitian menemukan bahwa dosis gabapentin $900 \mathrm{mg}$ lebih efektif daripada 600 mg dalam mengurangi nyeri pasca SS, konsumsi opioid, mual, dan muntah. Sedangkan ulasan sistematik dan meta-analisis RCT menunjukkan bahwa penggunaan profilaksis gabapentin oral 600 mg sebelum SS meningkatkan kontrol nyeri 
pascabedah pada pasien sehat (ASA I atau II) yang menjalani anestesi spinal dengan opioid intratekal, sama baiknya dengan yang mendapatkan OAINS dan asetaminofen pasca persalinan. ${ }^{1,30,31}$

Sebuah penelitian membandingkan antara gabapentin oral dengan pregabalin oral untuk mengurangi nyeri pascabedah pada pasien yang menjalani SS dengan anestesi spinal. Pada penelitian ini, pemberian pre-emtif pregabalin lebih efektif dibandingkan dengan gabapentin dalammengurangiinsentitasnyeriakutpascabedah dan mengurangi kebutuhan meperidin selama 24 jam pasca pembedahan tanpa efek samping serius. Berbeda dengan hasil penelitian tersebut, sebuah penelitian lain yang membandingkan pemberian pregabalin $300 \mathrm{mg}$ dan gabapentin $600 \mathrm{mg}$ dengan plasebo menyimpulkan bahwa pregabalin sama efektifnya dengan gabapentin tetapi lebih unggul daripada plasebo. ${ }^{32,33}$ Penelitian mengenai pemberian pregabalin 300 mg prabedah mengurangi konsumsi morfin dan nyeri akut pascabedah pada pasien SS dengan anestesi spinal. Akan tetapi, peneliti tidak yakin bahwa efek hemat morfin maternal menjustifikasi risiko peningkatan sedasi dan paparan bayi terhadap risiko pemberian pregabalin yang belum diketahui. Pada sebuah ulasan sistematis dengan meta-analisis dan analisis sekuensial penelitian mengenai manfaat dan bahaya pregabalin pada penatalaksanaan nyeri akut, disimpulkan bahwa berdasarkan beberapa penelitian dengan risiko bias rendah, pregabalin memiliki efek hemat opioid minimal, tetapi risiko efek samping serius tampaknya meningkat. Akan tetapi, evaluasi peringkat GRADE hanya menunjukkan bukti dengan kualitas menengah hingga sangat rendah. Akibatnya, penggunaan rutin pregabalin untuk penatalaksanaan nyeri pascabedah tidak dapat direkomendasikan. ${ }^{34,35}$

\section{Analgesia Neuraksial}

Sebagian besar SS dilakukan dengan anestesi neuraksial (teknik spinal, epidural, atau kombinasi spinal-epidural). Teknik ini memungkinkan pemberian obat-obat neuraksial untuk analgesia pascabedah. Pemberian opioid neuraksial saat ini merupakan baku emas untuk memberikan analgesia pasca SS yang efektif. Sebuah ulasan sistematik pada tahun 2010 menemukan bahwa morfin epidural dosis tunggal memberikan analgesia yang lebih baik dibandingkan dengan opioid parenteral setelah SS. Sebuah metaanalisis yang melibatkan populasi besar pasien yang menjalani berbagai prosedur pembedahan mengonfirmasi bahwa opioid yang diberikan dengan epidural PCA atau infus epidural kontinyu memberikan pengurangan nyeri yang lebih unggul dibandingkan dengan PCA intravena. Hasil serupa dilaporkan pada penelitian yang membandingkan pemberian opioid intratekal dan epidural dengan opioid PCA atau opioid intramuskuler setelah SS. ${ }^{1}$ Opioid neuraksial juga memberikan analgesia pasca SS yang lebih unggul dibandingkan dengan teknik regional non-neuraksial (blok TAP, infiltrasi luka operasi, dan obat analgesia oral). Walaupun analgesia neuraksial menawarkan manfaat yang penting dalam mengoptimalkan analgesia pasca pembedahan, strategi analgesia multimodal meningkatkan efek analgesia opioid neuraksial. Walaupun analgesia yang dihasilkan lebih unggul, beberapa efek samping terkait opioid (mis. pruritus) lebih sering terjadi pada pemberian opioid neuraksial. Skor kepuasan tertinggi dan terendah didapatkan pada kedua kelompok. Variabilitas tingkat kepuasan maternal dapat dipengaruhi oleh bagaimana pasien menilai kualitas analgesia dibandingkan dengan adanya dan beratnya efek samping. ${ }^{1}$

Klonidin intratekal maupun epidural (50-150 $\mathrm{mcg}$ ) dapat meningkatkan analgesia pasca SS ketika dihubungkan dengan obat anestesi lokal dan opioid. Akan tetapi, klonidin dapat menyebabkan hipotensi dan sedasi maternal. Penting untuk mempertimbangkan risiko klonidin pada wanita yang berisiko mengalami gangguan hemodinamik pasca SS dan karena hal ini, FDA Amerika menentang penggunaan rutin klonidin. Klonidin sebaiknya dipertimbangkan pada pasien yang berisiko tinggi mengalami nyeri akut refrakter pascabedah atau pasien dengan nyeri kronik. ${ }^{36}$ Neostigmin intratekal dapat meningkatkan analgesia pasca SS ketika dihubungkan dengan opioid seperti morfin. Akan tetapi, neostigmin merupakan obat kerja singkat dan berhubungan dengan insidens mual yang tinggi. American Society Guidelines for Postoperative Pain 


\title{
Tabel 1. Rekomendasi PROSPECT untuk Manajemen Nyeri Pasien yang Menjalani SS
}

\author{
Intervensi prabedah yang direkomendasikan untuk SS \\ Gabapentin oral Dosis tunggal gabapentin oral prabedah direkomendasikan (GoR A) untuk meningkatkan kontrol \\ nyeri pasca bedah (LoE 1)
}

Teknik anestesi dan obat analgesia yang diberikan bersamaan

Teknik anestesi: Anestesi kombinasi spinal-epidural atau

Analgesia opioid intratekal

Analgesia opioid epidural anestesi spinal

- $\quad$ Anestesi kombinasi spinal-epidural atau anestesi spinal direkomendasikan (GoR A) berdasarkan bukti khusus prosedur (LoE 1)

- $\quad$ Tidak ada bukti manfaat analgesia yang merekomendasikan anestesi umum daripada anestesi neuraksial (anestesi epidural, anestesi spinal, dan kombinasi spinal-epidural) dikarenakan kurangnya penelitian komparatif yang berfokus pada analgesia pasca bedah (GoR D) - $\quad$ Akan tetapi, teknik anestesi neuraksial direkomendasikan untuk alasan keamanan (mis. Anestesi neuraksial menyingkirkan kebutuhan manipulasi jalan napas dan mencegah efek sedatif anestesi umum pasca pembedahan) (GoR D)

- $\quad$ Morfin intratekal di bawah 200 mcg direkomendasikan jika pasien mendapatkan anestesi spinal (GoR A) berdasarkan bukti khusus prosedur untuk meningkatkan analgesia pasca bedah (LoE 1)

- $\quad$ Akan tetapi, dikarenakan efek samping terkait opioid yang meliputi depresi napas lambat, teknik analgesia alternatif sebaiknya dipertimbangkan

- $\quad$ Opioid epidural direkomendasikan jika pasien mendapatkan anestesi epidural (GoR A) berdasarkan bukti khusus prosedur untuk meningkatkan analgesia pasca bedah (LoE 1)

- $\quad$ Akan tetapi, dikarenakan efek samping terkait opioid yang meliputi depresi napas lambat, teknik analgesia alternatif sebaiknya dipertimbangkan

Teknik pembedahan yang direkomendasikan untuk SS

Teknik pembedahan: - $\quad$ Insisi abdomen transversal direkomendasikan daripada insisi vertikal (GoR A, LoE 1). Insisi abdomen transversal dan tidak menutup peritoneum Di antara insisi transversal, insisi Joel-Cohen dan modifikasi serupa lebih unggul dibandingkan insisi Pfannenstiel untuk luaran terkait nyeri pasca bedah (GoR A, LoE 1).

- $\quad$ Tidak menutup peritoneum direkomendasikan (GoR A) berdasarkan bukti khusus prosedur untuk analgesia pasca bedah (LoE 1)

Intervensi intraoperasi yang direkomendasikan untuk SS

\author{
OAINS intravena \\ pasca persalinan \\ Paracetamol intravena \\ pasca persalinan \\ Blok iliohipogastrik \\ dan ilioinguinal pasca \\ persalinan \\ Blok TAP bilateral \\ pasca persalinan \\ Infiltrasi luka pasca \\ persalunan dengan obat \\ anestesi lokal \\ OAINS pasca persalinan direkomendasikan (GoR A) berdasarkan bukti khusus prosedur (LoE 1), \\ bahkan pada wanita yang menyusui (LoE 3 ) \\ Paracetamol pasca persalinan direkomendasikan (GoR A) berdasarkan bukti khusus prosedur \\ (LoE 1) \\ Blok iliohipogastrik dan ilioinguinal bilateral direkomendasikan (GoR A) berdasarkan bukti \\ khusus prosedur untuk analgesia pasca bedah ( $\mathrm{LoE} 1)$ \\ Blok TAP bilateral direkomendasikan (GoR A) berdasarkan bukti khusus prosedur untuk analge- \\ sia pasca bedah (LoE 1) \\ Infiltrasi luka dengan obat anestesi lokal direkomendasikan (GoR A) berdasarkan bukti khusus \\ prosedur (LoE 1)
}

Intervensi pasca bedah yang direkomendasikan untuk SS

OAINS oral

OAINS pasca bedah direkomendasikan (GoR A) berdasarkan bukti khusus prosedur (LoE 1), bahkan pada wanita menyusui ( $\operatorname{LoE} 3)$

Paracetamol oral

Opioid sistemik

sebagai analgesia

penyelamat

Paracetamol pasca bedah direkomendasikan (GoR A) berdasarkan bukti khusus prosedur (LoE 1)

Infus luka operasi kontinyu dengan anestesi

lokal

GoR: Grade of Recommendation, LoE: Level of Evidence

(Dikutip dari: PROSPECT Working Group. Interventions that are recommended for C-section [online]. March 2019 [cited on November 23rd 2020]; Available from: URL: https://esraeurope.org/wp-content/uploads/2019/03/Summary-recommendations_C-section_EN.pdf
Opioid sistemik memberikan analgesia yang efektif (GoR A, LoE 1), tetapi hanya direkomendasikan sebagai analgesia penyelamat dikarenakan efek sampingnya (GoR D)

Infus luka operasi kontunyu dengan obat anestesi lokal direkomendasikan (GoR A) berdasarkan bukti khusus prosedur (LoE 1) 
Management 2016 tidak merekomendasikan pemberian neostigmin neuraksial dikarenakan manfaatnya masih belum jelas dan bukti untuk menentukan keamanannya belum cukup tersedia. Epinefrin tidak menunjukkan peningkatan yang konsisten pada analgesia dan efek samping sehubungan dengan opioid, baik pada pemberian epidural maupun intratekal. Sedangkan pemberian antagonis NMDA, seperti ketamin dan magnesium tampaknya aman dan efektif, tetapi penelitian yang mendasari masih terbatas. ${ }^{36}$ Teknik neuraksial memberikan manfaat lain selain analgesia pascabedah yang lebih baik, yang meliputi peningkatan kemampuan fungsional, ambulasi dini, dan kembalinya fungsi usus lebih cepat. Manfaat potensial lainnya antara lain insidens infeksi paru dan emboli paru yang lebih rendah, gangguan kardiovaskuler dan koagulasi yang sedikit, dan penurunan respon inflamasi dan stres yang diinduksi pembedahan. ${ }^{1}$

\section{Analgesia Multimodal}

Analgesia multimodal menyeimbangkan efektivitas obat analgesia, memaksimalkan efikasi sambil meminimalkan efek samping. Rasional analgesia multimodal adalah optimalisasi efek aditif atau sinergistik beberapa jenis analgesia atau kelas obat berbeda, sambil mengurangi dosis dan meminimalkan efek samping obat dengan mekanisme kerja yang berbeda. Walaupun efikasi obat analgesia merupakan tujuan utama, tujuan sekunder yang tidak kalah pentingnya antara lain meminimalkan transfer obat ke ASI dan mengurangi efek samping maternal yang dapat mengganggu ASI atau proses menyusui. ${ }^{1}$ Berbagai kombinasi opioid, obat antiinflamasi non-steroid (OAINS), asetaminofen (paracetamol), dan obat anestesi lokal dapat digunakan dengan berbagai derajat keberhasilan. Beberapa penelitian menunjukkan analgesia yang lebih unggul ketika diberikan secara oral dengan interval terjadwal dibandingkan dengan pemberian jika diperlukan. Rekomendasi terbaru dari ACOG yang didukung beberapa penelitian merekomendasikan penggunaan opioid hanya sebagai analgesia penyelamat dan bukan sebagai obat yang diberikan secara rutin. Pemberian kombinasi analgesia non-opioid dengan dosis terjadwal terbukti dapat mengurangi nyeri pasca SS tanpa penggunaan opioid. Hal ini dapat mengurangi penggunaan dan efek samping opioid terhadap wanita yang menjalani SS dan bayi yang diberikan ASI. ${ }^{1,29}$

\section{Pertimbangan Maternal dan Fetal}

Analgesia yang baik mendorong keberhasilan pemberian ASI dan ikatan ibu dan bayi, tetapi obat analgesia berpotensi ditransferkan pada bayi yang menyusui. Paparan obat neonatus utamanya diekspresikan sebagai dosis infan relatif relative infant dose/RID. RID memperhitungkan berat badan ibu dan bayi dan RID lebih dari 10\% umumnya dianggap batas level yang harus diperhatikan. Tabel 1 menunjukkan RID obat analgesia yang umum digunakan untuk manajemen nyeri pasca SS. ${ }^{38}$

Obat analgesia pascabedah untuk wanita menyusui diberikan dengan mempertimbangkan beberapa prinsip umum berikut: ${ }^{38}$ analgesia multimodal hemat opioid lebih dipilih, karena opioid berhubungan dengan transfer obat ke

Tabel 2. Potensi Transfer ke ASI Obat Analgesia yang Sering Digunakan setelah SS

\begin{tabular}{ll}
\hline Obat Analgesia & Dosis Infan Relatif $(\%)$ \\
\hline Opioid & \\
Morfin & $5,8-10,7$ \\
Fentanyl & $0,9-3$ \\
Oksikodon & $1,5-8$ \\
Hidrokodon & $1,6-3,7$ \\
Tramadol & $2,4-2,9$ \\
Non-opioid & \\
Ibuprofen & $0,1-0,7$ \\
Ketorolak & $0,2-0,4$ \\
Celecoxib & 0,3 \\
Asetaminofen & $1,3-6,4$ \\
Deksametason & Tidak ada data \\
Gabapentin & $1,3-6,5$ \\
Pregabalin & Tidak ada data \\
\hline
\end{tabular}

Dikutip dari: Sutton CD, Carvalho B. Optimal pain management after cesarean delivery. Anesth Clin. 2016;35(1):P107-24; Carvalho B, Butwick AJ. Postcesarean delivery analgesia. Best Pract Res Clin Anaesth. 2017;31:69-79 
ASI dan dapat menyebabkan sedasi neonatus; jumlah obat di dalam ASI paralel dengan kadar obat maternal. Sebaiknya digunakan dosis efektif terendah dan pemberian opioid intratekal atau epidural dibandingkan opioid intravena jika memungkinkan; obat-obat dengan waktu paruh singkat, metabolit yang tidak aktif, dan memiliki riwayat penggunaan yang aman merupakan pilihan terbaik pada keadaan ini.

\section{Simpulan}

Manajemen nyeri pasca SS bertujuan untuk memberikan kenyamanan pada pasien, menghambat impuls nosiseptif, menumpulkan respon neuroendokrin terhadap nyeri yang dengan demikian mempercepat kembalinya fungsi fisiologis, memungkinkan mobilisasi dini untuk mencegah risiko tromboemboli yang meningkat selama kehamilan, dan dalam rangka pemberian ASI yang efektif. Analgesia multimodal merupakan pendekatan yang tepat untuk tatalaksana nyeri pasca pembedahan pada pasien yang menjalani SS, dapat dipertimbangkan sesuai dengan pilihan dan kebutuhan masing-masing individu sesuai rekomendasi PROSPECT dan memperhatikan potensi transfer obat analgesia ke dalam ASI.

\section{Daftar Pustaka}

1. George RB, Carvalho B, Butwick A, Flood P. Postoperative analgesia. In: Chesnut DH, Wong CA, Tsen LC, Ngan Kee WD, Beilin Y, Mhyre JM, Bateman BT, editors. Chesnut's obstetric anesthesia, principles and practice, 6th Ed. Philadelphia: Elsevier; 2020. 627-56.

2. Ismail S. What is new in postoperative analgesia after caesarean sectios? Anaesth Pain Intensive Care. 2012;16(2):123-6.

3. Kintu A, Abdulla S, Lubikire A, Nabukenya MT, Igaga E, Bulamba F, et al. Postoperative pain after cesarean section: assessment and management in a tertiary hospital in a lowincome country. BMC Health Serv Res. 2019;19:68.
4. Kuczkowski KM. Postoperative pain control in the parturient: new challenges in the new millennium. J Mater Fetal Neonat Med. 2011;24(2):301-4.

5. Yam MF, Loh YC, Tan CS, Adam SK, Manan NA, Basir R. General pathways of pain sensation and the major neurotransmitters involved in pain regulation. Int J Mol Sci. 2018;19(2164):1-23.

6. Rao M. Acute postoperative pain. Indian J Anaesth. 2006;50(5):340-4.

7. Woolf CJ, Chong MS. Preemptive analgesia - treating postoperative pain by preventing the establishment of central sensitization. Anesth Analg. 1993;77:362-79.

8. Altenau B, Crisp CC, Devaiah CG, Lamber DS. Randomized controlled trial of intravenous acetaminophen for post-cesarean delivery pain control. Am J Obstet Gynec. 2017;217(3):362.E1-6.

9. Moghadam SHP, Pourparizi M, Goujani R, Khalilabadi TM, Ravari A, Askari S, et al. Analgesic effect of preoperative intravenous administration of paracetamol on postcesarean pain: A randomized clinical trial. BMC Preg Child. 2019;1-18.

10. Rani KU, Zutshi V, Patel M, Marwah S. Analgesic efficacy of intravenous paracetamol versus intravenous tramadol after caesarean section: a single blind randomized controlled study. Inter J Repro Contracep Obstet Gynec. 2016;5(12):4285-9.

11. Zakaria AEMM, Mohammed AH, Hammour ME, Refaie MA. Comparative study between intravenous paracetamol and pethidine as post-cesarean section analgesia. Egypt $\mathrm{J}$ Hosp Med. 2018;71(6):3314-21.

12. Hamburger J, Beilin Y. Systemic adjunct analgesics for cesarean delivery: a narrative review. Inter J Obstet Anesth. 2019;40:10118. 
13. Zeng AM, Nami NF, Wu CL, Murphy JD. The analgesic efficacy of nonsteroidal antiinflammatory agents (NSAIDs) in patients undergoing cesarean deliveries. Obstet Analg. Reg Anesth Pain Med. 2016;41(6):763-72.

14. Hirshberg JS, Cahill AG. Pain relief: determining the safety of ibuprofen with postpartum preeclampsia. Am $\mathrm{J}$ Obstet Gynec. 2018:548.

15. Vigil-De Gracia P, Solis V, Ortega N. Ibuprofen versus acetaminophen as a postpartum analgesic for women with severe pre-eclampsia: randomized clinical study. $\mathrm{J}$ Mater Fetal Neonat Med. 2017;30(11):1-16.

16. Penfield CA, McNulty JA, Oakes MC, Nageotte MP. Ibuprofen and postpartum blood pressure in women with hypertensive disorders of pregnancy: a randomized controlled trial. Obstet Gynec. 2019;134(6):1219-26.

17. Mahon V, Chamchad D, Horrow JC, Gerson A, Brest N. A randomized double-blind comparison of iv ibuprofen vs iv ketorolac to prevent postoperative pain after scheduled cesarean section. 2016;4(3):1-6.

18. Shakeri A, Razavi M, Mirkahnuj Z. Comparison of the effect of pregabaline and diclofenac suppository on pain relief after elective cesarean section. J Pharma Res Inter. 2019;31(6):1-6.

19. Ramos-Rangel GE, Ferrer-Zaccaro LE, Mojica-Manrique VL, La Rotta MG. Management of post-cesarean delivery analgesia: pharmacologic strategies. Rev Colomb Anest. 2017;45(4):327-34.

20. Kasemsin P, Suwannarurk K, Pongrojpaw D, Chanthasenanont A, Lertvutivivat S, Pattaraarchachai J, et al. Effect of intravenous ketorolac on postoperative pain after cesarean section: a randomized doubleblinded controlled trial. J Med Assoc Thai. 2017;100(Suppl.5):S168-74.
21. Yurashevich M, Pedro C, Fuller M, Habib AS. Intra-operative ketorolac $15 \mathrm{mg}$ versus $30 \mathrm{mg}$ for analgesia following cesarean delivery: a retrospective study. Inter J Obstet Anesth. 2020;44:116-21.

22. Inthigood N, Lertbunnaphong T, Jaishuen A. efficacy of a single 40-mg intravenous dose of parecoxib for postoperative pain control after elective cesarean delivery: a doubleblind randomized placebo-controlled trial. J Obstet Gynec Res. 2017;43(1):92-9.

23. Carvalho B, Butwick AJ. Postcesarean delivery analgesia. Best Pract Res Clin Anaesth. 2017;31:69-79.

24. Ituk U, Thenuwara $\mathrm{K}$. The effect of a single intraoperative dose of intravenous dexamethasone $8 \mathrm{mg}$ on post-cesarean delivery analgesia: a randomized controlled trial. Inter J Obs Anesth. 2018;35:57-63.

25. Maged AM, Seeb WS, Elbaradie S, Elzayat AR, Metwally AA, Hamed M, et al. Comparison of local and intra venous dexamethasone on post operative pain and recovery after caeseream section: a randomized controlled trial. Taiwan J Obstet Gynec. 2018;57:346-50.

26. Melese E, Tesfaye A, Getachew L, Daniel T. Analgesic Effect of Intravenous Dexamethasone Prior to Spinal Anesthesia Among Parturient Undergo Cesarean Section at Gandhi Memorial Hospital, Addis Ababa, Ethiopia, Prospective Cohort Study, 2019. J Anesth Clin res. 2019;10:12.

27. Cao X, Zhang X. Comparison of different sufentanil-tramadol combinations for pain relief within the first 24 hours after cesarean section: a retrospective study. J Pain Res. 2018;11:2445-51.

28. Makela K, Palomaki O, Pokkinen S, YliHankala A, Helminen M, Uotila J. Oral versus patient-controlled intravenous administration of oxycodone for pain relief after cesarean 
section. Arch Gynec Obstet. 2019;300:903-9.

29. Holland E, Bateman BT, Cole N, Taggart A, Robinson LA, Sugrue R, et al. Evaluation of a quality improvement intervention that eliminated routine use opioids after cesarean delivery. Obstet Gynec. 2019;133:91-7.

30. El Saied Hafiz MH, El Din Abdelhamid $\mathrm{MH}$, Youssef MMI, Abdelrahim IKH. Randomized controlled trial of two oral regimens of gabapentin versus placebo in patients for Cesarean section under spinal anesthesia regarding postoperative pain, sedation, nausea, and vomiting. Egypt J Anaesth. 2017;33:59-65.

31. Felder L, Saccone G, Scuotto S, Monks DT, Carvalho JCA, Zullo F, et al. Perioperative gabapentin and post cesarean pain control: a systematic review and meta-analysis of randomizeed controlled trials. Europ J Obstet Gynec Repro Bio. 2019;233:98-106.

32. Alaasar NM, Soud DEM, El-Deen AM, Elfattah IAA. Oral gabapentin versus pregabalin for postoperative pain relief in elective cesarean section patients under spinal anesthesia. Egypt J Hosp Med. 2020;81(1):1330-7.

33. Gupta S, Aggarwal A, Sharma R. Preemptive gabapentin vs pregabalin for acute postoperative pain in women undergoing cesarean section under spinal anesthesia: a prospective randomized double-blind study. Indian J Anesth Analg. 2019;6(5):1852-6.

34. El Kenany S, El Tahan MR. Effect of preoperative pregabalin on post-caesarean delivery analgesia: a dose response study. 2016;26:24-31.

35. Fabritius ML, Strom C, Koyuncu S, Jaeger P, Petersan PL, Geisler A, et al. Benefit and harm of pregabalin in acute pain treatment: a systematic review with meta-analyses and trial sequential analyses. Britis J Anaesth. 2017;119(4):775-91.

36. Arroyo-Fernandez FJ, Calderon-Seoane JE, Torres-Morera LM. Strategies of analgesic treatment after cesarean delivery: current state and new alternatives. Rev Esp Anest Reanim. 2020;67(3):167-75.

37. PROSPECT Working Group. Interventions that are recommended for $\mathrm{C}$-section [online]. March 2019 [cited on November 23rd 2020]; Available from: URL: https://esraeurope. org/wp-content/uploads/2019/03/Summaryrecommendations_C-section_EN.pdf.

38. Sutton CD, Carvalho B. Optimal pain management after cesarean delivery. Anesth Clin. 2016;35(1):107-24. 